\title{
Another hitchhiker exposed: Diceratocephala boschmai (Platyhelminthes: Temnocephalida) found associated with ornamental crayfish Cherax spp.
}

\author{
Filip Ložek ${ }^{1, *}$, Jiří Patoka ${ }^{2}$ and Martin Bláha ${ }^{1}$ \\ ${ }^{1}$ South Bohemian Research Center of Aquaculture and Biodiversity of Hydrocenoses, Faculty of Fisheries and Protection of Waters, \\ University of South Bohemia in České Budějovice, Zátiší 728/II, Vodňany 389 25, Czech Republic \\ ${ }^{2}$ Department of Zoology and Fisheries, Faculty of Agrobiology, Food and Natural Resources, Czech University of Life Sciences Prague, \\ Kamýcká 129, Prague - Suchdol 165 00, Czech Republic
}

Received: 6 May 2021 / Accepted: 21 May 2021

\begin{abstract}
There are known plenty tiny invertebrate species associated with decapod crustaceans. Our contribution documents the first record of New Guinean ornamental Cherax crayfish epibiont, Diceratocephala boschmai (Platyhelminthes: Temnocephalida) found in pet trade in the Czech Republic. Correct species assignment was confirmed by genetic barcoding. The pathway for introductions of organisms unintentionally moved in association with ornamental crayfish via the international trade has been highlighted. Although Cherax species survive in thermal waters in Europe, even potential introduction to these habitats posed threat to native crayfish ectosymbionts (branchiobdellids) thought similar ecological niche.
\end{abstract}

Keywords: Ectosymbiont / alien species / ornamental species / pet trade / Europe / New Guinea

\begin{abstract}
Résumé - Un autre hitchhiker dévoilé: Diceratocephala boschmai (Platyhelminthes: Temnocephalida) trouvé associé aux écrevisses ornementales Cherax spp. On connaît de nombreuses espèces de petits invertébrés associés à des crustacés décapodes. Notre contribution documente le premier enregistrement de l'épibionte de l'écrevisse Cherax ornementale de NouvelleGuinée, Diceratocephala boschmai (Platyhelminthes: Temnocephalida) trouvé dans le commerce des animaux de compagnie en République tchèque. L'attribution correcte des espèces a été confirmée par un code-barres génétique. La voie d'introduction d'organismes déplacés involontairement en association avec des écrevisses ornementales via le commerce international a été mise en évidence. Alors que les espèces de Cherax survivent dans les eaux thermales en Europe, même une introduction potentielle dans ces habitats constitue une menace pour les ectosymbiontes d'écrevisses indigènes (branchiobdellidés) dont la niche écologique est similaire.
\end{abstract}

Mots-clés : Ectosymbionte / espèces exotiques / espèces ornementales / commerce des animaux de compagnie / Europe / Nouvelle-Guinée

Anthropogenic translocation of species together with subsequent biological invasions are considered among major threats causing biodiversity alteration in the aquatic ecosystems worldwide (Rodríguez et al., 2005). One of the main pathways for non-native species introduction is international pet trade (Patoka et al., 2018; Marková et al., 2020). Although decapod crustaceans are relatively new to the pet trade (Chucholl, 2013; Faulkes, 2015; Patoka et al., 2015), especially colourful species of Cherax quickly became very popular (Patoka, 2020). With increasing number of imports from Indonesia,

\footnotetext{
${ }^{*}$ Corresponding author: lozekf@jcu.cz
}

likelihood to import of so-called hitchhikers increase as well (Patoka et al., 2015). Alien epibionts are usually overlooked (Dörr et al., 2011; Patoka et al., 2016a,b, 2020; Duggan and Pullan, 2017; Duggan et al., 2018) unless they represent real threat to ecosystem where their hosts were introduced (Ohtaka et al., 2005). Up to now, mostly North American representatives of brachniobdellids (Annelida: Branchiobdellida) were introduced and found in European waters (James et al., 2015; Parpet and Gelder, 2020) following their North American crayfish hosts (mostly Procambarus clarkii and Pacifastacus leniusculus). Natural epibionts of the North Hemisphere crayfish are branchiobdellids (Annelida), while Southern hemisphere crayfish are infested 
by temnocephalids (Platyhelminthes) (Gelder, 1999). Populations of Australian Cherax crayfish are already established in some European localities (Scalici et al., 2009; Jaklič and Vrezec, 2011; Mazza et al., 2018; Weiperth et al., 2019; Weiperth et al., 2020; Arias Rodríguez and Torralba Burrial, 2021), however up to now only Temnosewellia minor was reported from Italy associated with $C$. destructor (Chiesa et al., 2015; Vecchioni et al., 2021), and with North American P. clarkii (Mazza et al., 2018). Just recently, Scutariella japonica has been recorded on freshwater shrimps in thermally polluted waters in Poland (Maciaszek et al., 2021). Nevertheless, occurrence of temnocephalids out of their natural range was reported on crayfish in Uruguay (Volonterio, 2009), South Africa (Mitchell and Kock, 1988; Du Preez and Smit, 2013; Tavakol et al., 2016) and Thailand (Ngamniyom, 2020). Therefore, the aim of this study was to point out on unintentional translocation of hitchhikers through international pet trade of their hosts, and to suggest preventive measures against introduction out of their natural range.

In total, 40 adult individuals of various Cherax species (C. alyciae, C. gherardii, C. peknyi, and several individuals of Cherax sp. "Black Scorpion" and C. cf. boesemani) were superficially inspected for potential epibionts after their arrival in one batch import from Indonesia on 13 October 2020, when no obvious epibionts were found. After two months in aquaria within closed recirculation system, one adult temnocephalidan was found on the bottom part of carapace in one Cherax individual. Together with adult individual, many eggs were recorded in surroundings (Fig. 1). Later more adult individuals were found on this specific crayfish individual, attached under rostrum ( 2 ind.), on the bottom of carapace ( 2 ind.) and at the base of abdomen ( 2 ind.).

Two temnocephalidans were removed from crayfish and placed directly into lysis buffer. Total genomic DNA was extracted using E.Z.N.A. ${ }^{\circledR}$ Tissue DNA Mini Kits (Peqlab, Erlangen, Germany). Fragments of mitochondrial genes Cytochrome c oxidase subunit I and nuclear 28S rDNA were amplified using PCR primers 450F/1200R and Ltem180/ Ltem1000R, respectively following protocol of Hoyal Cuthill et al. (2016). PCR products were purified with NucleoSpin ${ }^{\circledR}$ (Macherey-Nagel, Düren, Germany) and sequenced on an ABI automatic capillary sequencer (series 373) (Macrogen, Seoul, Korea), using amplification primers.

Morphology as well as genetic barcoding showed clear assignment to the species of Diceratocephala boschmai Baer, 1953. Blast analysis reveals $99 \%$ identity with COI sequence MK421403 and 404, and 28S rRNA sequence KM588103 of D. boschmai available at GenBank database. Sequences originated in this study are deposited in GenBank under accession numbers MZ128776 for COI and MZ087752 for 28S gene.

Despite our first observations of two adult individuals of D. boschmai surrounded by their eggs on one crayfish host, during following 60 days the host was highly infested. Moreover, temnocephalids subsequently infested other crayfish individual which was kept separately but in the same recirculation system. This fact is highlighting potential of high spreading ability under suitable conditions (water temperature was $25 \pm 2{ }^{\circ} \mathrm{C}$ ). The temnocephalid associated with their Cherax crayfish hosts can be probably found in many species collected in wild in New Guinea. This assumption was confirmed by temnocephalid eggs recorded on adult

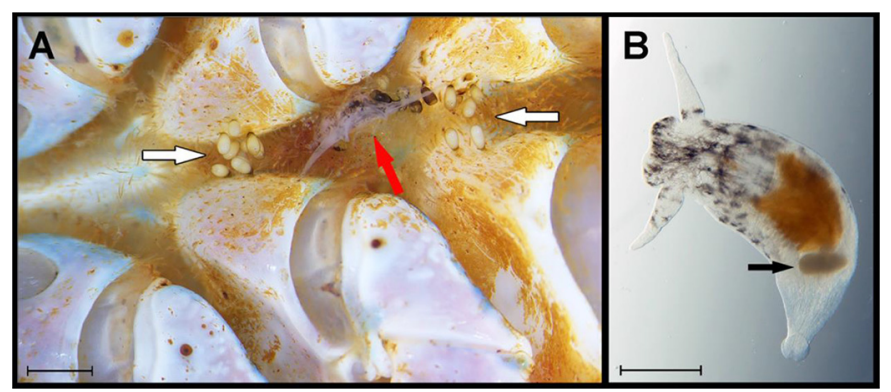

Fig. 1. Position of Diceratocephala boschmai (red arrow) and its eggs (white arrows) attached on the bottom part of carapace (A), and detail of epibiont with egg ready to be laid (black arrow) as well as gut content (B). The scale bar is equal to one millimeter.

C. monticola (Fig. 2) offered for sale in Wibama market in Wamena, Papua Province, Indonesian part of New Guinea in 2017 within astacological expedition to Yumugima cave system (Patoka et al., 2017) by two authors of this publication (Patoka and Bláha, 2017, unpublished data).

Presence of alien epibionts in Europe following the aquatic invasions of decapods is actual topic (Chiesa et al., 2015; James et al., 2015; Mazza et al., 2018; Parpet and Gelder, 2020; Maciaszek et al., 2021; Vecchioni et al., 2021). Global pet trade with increasing attractivity of ornamental decapods together with their current commercial availability is considered as a relevant risk of alien hitchhikers future introductions (Chucholl and Wendler, 2017; Yonvitner et al., 2020). Additionally, the high invasive potential of C. quadricarinatus, the species widely used in aquaculture and introduced to many countries out of the original area of distribution has recently been discussed (Akmal et al., 2021; Haubrock et al., 2021) and thus representing high potential risk of native epibionts introductions. Even if policymakers generally focused on regulation of spread and introductions of potentially invasive species in European Union (Regulation (EU) No 1143/2014), the current legislative framework is ineffective in many cases (Patoka et al., 2018). Our finding of D. boschmai on imported crayfish showed insufficient preventive measures on wildcaught crayfish in the place of export. However even including such measures do not ensure epibionts on transported animals or plants (Patoka et al., 2016b; Duggan et al., 2018). It is worth mentioning that certain epibionts, including temnocephalids would potentially spread in Europe similarly to North American branchiobdellids (Parpet and Gelder, 2020; Vecchioni et al., 2021) as already shown on Scuteriella japonica, temnocephalid epibiont of freshwater shrimps (Maciaszek et al., 2021). The only difference that their distribution would be related to warmer south parts, thermal or thermally polluted streams in Europe.

Together with previously reported host opportunism of ectosymbionts (James et al., 2017; Mazza et al., 2018) they could serve as vectors of pathogens to their non-indigenous hosts (Ngamniyom, 2020). We presume potential direct risk for native European epibionts based on our observation. Digestive tract of individuals of $D$. boschmai contained periphyton, cyclopoid copepods and chironomid larvae suggesting omnivorous feeding strategy. In case of common occurrence, smaller European branchiobdellids such as 


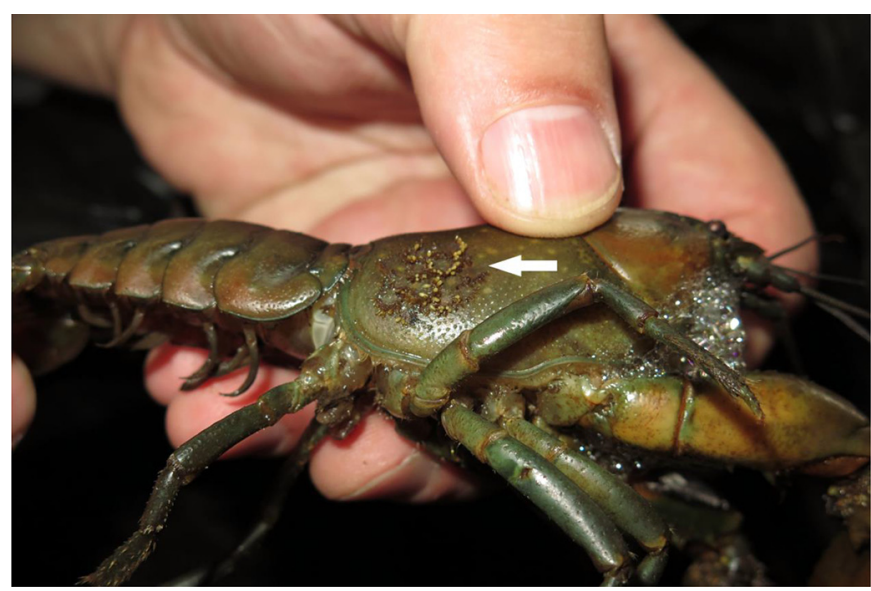

Fig. 2. Temnocephalid eggs located on thorax carapace (white arrow) of adult Cherax monticola.

\section{B. pentadonta or $B$. hexadonta could become a prey for bigger D. boschmai.}

To reduce the spreading probability of the epibionts, the attention should be therefore focused on strict multiplied three-phases preventive measures according to manipulation with wild-caught animals and their exporting: (i) disinfection bath of wild-caught individuals; (ii) quarantine before adding to stock tanks; and (ii) regular periodical sanitation of stock tanks. Similar procedure is suggested for pet shops in areas of imported animals as well as to final customer who should follow the preventive procedure for newly purchased animals.

Future experiments focused on behaviour of D. boschmai in interactions with native branchiobdellids to ascertain the potential risk are recommended.

Acknowledgements. FL and MB were partly supported by Grant agency of Czech Republic (19-04431S), while JP was supported by the Technology Agency of the Czech Republic within the project "DivLand" (SS02030018).

\section{References}

Akmal SG, Santoso A, Yuliana E, Patoka J. 2021. Redclaw crayfish (Cherax quadricarinatus): spatial distribution and dispersal pattern in Java, Indonesia. Knowl Manag Aquat Ecosyst 422: 16.

Arias Rodríguez A, Torralba Burrial A. 2021. First record of the redclaw crayfish Cherax quadricarinatus (Von Martens, 1868) on the Iberian Peninsula. Limnetica 40.

Chiesa S, Scalici M, Lucentini L, Nonnis Marzano F. 2015. Molecular identification of an alien temnocephalan crayfish parasite in Italian freshwaters. Aquat Invasions 10: 209-216.

Chucholl C. 2013. Invaders for sale: trade and determinants of introduction of ornamental freshwater crayfish. Biol Invasions 15: 125-141.

Chucholl C, Wendler F. 2017. Positive selection of beautiful invaders: long-term persistence and bio-invasion risk of freshwater crayfish in the pet trade. Biol Invasions 19: 197-208.

Dörr AJ, Rodolfi M, Scalici M, Elia AC, Garzoli L, Picco AM. 2011. Phoma glomerata, a potential new threat to Italian inland waters. J Nat Conserv 19: 370-373.
Du Preez L, Smit N. 2013. Double blow: Alien crayfish infected with invasive temnocephalan in South African waters. South Afr J Sci 109: $1-4$

Duggan IC, Champion PD, MacIsaac HJ. 2018. Invertebrates associated with aquatic plants bought from aquarium stores in Canada and New Zealand. Biol Invasions 20: 3167-3178.

Duggan IC, Pullan SG. 2017. Do freshwater aquaculture facilities provide an invasion risk for zooplankton hitchhikers? Biol Invasions 19: 307-314.

Faulkes Z. 2015. The global trade in crayfish as pets. Crustacean Res 44: 75-92.

Gelder SR. 1999. Zoogeography of branchiobdellidans (Annelida) and temnocephalidans (Platyhelminthes) ectosymbiotic on freshwater crustaceans, and their reactions to one another in vitro. Hydrobiologia 406: 21-31.

Haubrock PJ, Oficialdegui FJ, Zeng Y, Patoka J, Yeo DC, Kouba A. 2021. The redclaw crayfish: a prominent aquaculture species with invasive potential in tropical and subtropical biodiversity hotspots. Rev Aquacult doi.org/10.1111/raq.12531.

Hoyal Cuthill JF, Sewell KB, Cannon LR, Charleston MA, Lawler S, Littlewood DTJ, Olson PD, Blair D. 2016. Australian spiny mountain crayfish and their temnocephalan ectosymbionts: an ancient association on the edge of coextinction? Proc Roy Soc B: Biol Sci 283. doi: 10.1098/rspb.2016.0585.

Jaklič M, Vrezec A. 2011. The first tropical alien crayfish species in European waters: the redclaw Cherax quadricarinatus (Von Martens, 1868) (Decapoda, Parastacidae). Crustaceana 651-665.

James J, Cable J, Richardson G, Davidson K, Mackie A. 2015. Two alien species of Branchiobdellida (Annelida: Clitellata) new to the British Isles: a morphological and molecular study. Aquat Invasions 10: 371-383.

James J, Davidson KE, Hunt R, Cable J. 2017. Assessing the invasion potential of non-native branchiobdellidans: experimental studies of survival, reproduction and competition. Knowl Manag Aquat Ecosyst 418: 35.

Maciaszek R, Świderek W, Kaliszewicz A, Karaban K, Szpakowski B. 2021. First report of Scutariella japonica (Matjašič, 1990), a temnocephalid epibiont from South-East Asia, found on introduced ornamental freshwater shrimp in European waters. Knowl Manag Aquat Ecosyst 422: 19.

Marková J, Jerikho R, Wardiatno Y, Kamal MM, Magalhães ALB, Bohatá L, Kalous L, Patoka J. 2020. Conservation paradox of giant arapaima Arapaima gigas (Schinz, 1822) (Pisces: Arapaimidae): endangered in its native range in Brazil and invasive in Indonesia. Knowl Manag Aquat Ecosyst 421: 47.

Mazza G, Scalici M, Inghilesi AF, Aquiloni L, Pretto T, Monaco A, Tricarico E. 2018. The red Alien vs. the blue Destructor: the eradication of Cherax destructor by Procambarus clarkii in Latium (Central Italy). Diversity 10: 126.

Mitchell S, Kock D. 1988. Alien symbionts introduced with imported marron from Australia may pose a threat to aquaculture. South Afr J Sci 84: 877-878.

Ngamniyom A. 2020. First evidence of Craspedella pedum (Cannon and Sewell, 1995) (Platyhelminthes: Rhabdocoela) infesting alien red swamp crayfish with white spot syndrome virus infections collected from Thailand. BioInvas Records 9: 340-348.

Ohtaka A, Gelder SR, Kawai T, Saito K, Nakata K, Nishino M. 2005. New records and distributions of two North American branchiobdellidan species (Annelida: Clitellata) from introduced signal crayfish, Pacifastacus leniusculus, in Japan. Biol Invasions 7: 149-156.

Parpet J-F, Gelder S. 2020. North American Branchiobdellida (Annelida: Clitellata) or Crayfish Worms in France: the most 
diverse distribution of these exotic ectosymbionts in Europe. Zoosymposia 17: 121-140.

Patoka J. 2020. Crayfish of New Guinea: Current status, exploitation and threats. In: Ribeiro, FB (ed.), Crayfish: Evolution, Habitat and Conservation Strategies. New York: Nova, 43-69.

Patoka J, Bláha M, Devetter M, Rylková K, Čadková Z, Kalous L. 2016a. Aquarium hitchhikers: attached commensals imported with freshwater shrimps via the pet trade. Biol Invasions 18: 457-461.

Patoka J, Bláha M, Kalous L, Vrabec V, Buřič M, Kouba A. 2016b. Potential pest transfer mediated by international ornamental plant trade. Sci Rep 6.

Patoka J, Bláha M, Kouba A. 2017. Cherax acherontis (Decapoda: parastacidae), the first cave crayfish from the Southern Hemisphere (Papua Province, Indonesia). Zootaxa 4363: 137-144.

Patoka J, Kalous L, Kopecký O. 2015. Imports of ornamental crayfish: the first decade from the Czech Republic's perspective. Knowl Manag Aquat Ecosyst 416: 04.

Patoka J, Magalhães ALB, Kouba A, Faulkes Z, Jerikho R, Vitule JRS. 2018. Invasive aquatic pets: failed policies increase risks of harmful invasions. Biodivers Conserv 27: 3037-3046.

Patoka J, Prabowo RE, Petrtýl M, Reynolds JD, Kuř́ková P, Zámečníková-Wanma BP, Kalous L. 2020. Marine hitchhikers: a preliminary study on invertebrates unintentionally transported via the international pet trade. NeoBiota 61: 33 .

Rodríguez C, Bécares E, Fernández-Aláez M, Fernández-Aláez C. 2005. Loss of diversity and degradation of wetlands as a result of introducing exotic crayfish. Biol Invasions 7: 75-85.
Scalici M, Chiesa S, Gherardi F, Ruffini M, Gibertini G, Marzano FN. 2009. The new threat to Italian inland waters from the alien crayfish "gang": the Australian Cherax destructor Clark, 1936. Hydrobiologia 632: 341-345.

Tavakol S, Luus-Powell WJ, Smit WJ, Baker C, Hoffman A, Halajian A. 2016. First introduction of two Australian temnocephalan species into Africa with an alien host: double trouble. J Parasitol 102: 653-658.

Vecchioni L, Chirco P, Bazan G, Marrone F, Arizza V, Arculeo M. 2021. First record of Temnosewellia minor (Platyhelminthes, Temnocephalidae) in Sicily, with a plea for a re-examination of the identity of the publicly available molecular sequences of the genus. Biogeographia 36.

Volonterio O. 2009. First report of the introduction of an Australian temnocephalidan into the New World. J Parasitol 95: 120-123.

Weiperth A, Bláha M, Szajbert B, Seprös R, Bányai Z, Patoka J, Kouba A. 2020. Hungary: a European hotspot of non-native crayfish biodiversity. Knowl Manag Aquat Ecosyst 421: 43.

Weiperth A, Gal B, Kuř́ková P, Langrová I, Kouba A, Patoka J. 2019. Risk assessment of pet-traded decapod crustaceans in Hungary with evidence of Cherax quadricarinatus (von Martens, 1868) in the wild. North-Western J Zool 15: 42-47.

Yonvitner Y, Patoka J, Yuliana E, Bohatá L, Tricarico E, Karella T, Kouba A, Reynolds JD. 2020. Enigmatic hotspot of crayfish diversity at risk: Invasive potential of non-indigenous crayfish if introduced to New Guinea. Aquat Conserv Mar Freshw Ecosyst 30: 219-224.

Cite this article as: Ložek F, Patoka J, Bláha M. 2021. Another hitchhiker exposed: Diceratocephala boschmai (Platyhelminthes: Temnocephalida) found associated with ornamental crayfish Cherax spp. Knowl. Manag. Aquat. Ecosyst., 422, 25. 